\title{
Lu Xun, Errances (Wandering)
}

scholarly edition by Sébastian Veg, Paris, Editions Rue d'Ulm, 2004, 352

p.

Isabelle Rabut

\section{OpenEdition}

\section{Journals}

\section{Édition électronique}

URL : http://journals.openedition.org/chinaperspectives/534

DOI : 10.4000/chinaperspectives.534

ISSN : 1996-4617

Éditeur

Centre d'étude français sur la Chine contemporaine

\section{Édition imprimée}

Date de publication : 1 octobre 2005

ISSN : 2070-3449

\section{Référence électronique}

Isabelle Rabut, "Lu Xun, Errances (Wandering) », China Perspectives [En ligne], 61 | september-october 2005, mis en ligne le 18 décembre 2006, consulté le 21 septembre 2020. URL : http://

journals.openedition.org/chinaperspectives/534; DOI : https://doi.org/10.4000/chinaperspectives. 534

Ce document a été généré automatiquement le 21 septembre 2020.

(C) All rights reserved 


\section{Lu Xun, Errances (Wandering)}

scholarly edition by Sébastian Veg, Paris, Editions Rue d'Ulm, 2004, 352

p.

Isabelle Rabut

\section{NOTE DE L'ÉDITEUR}

Translated from the French original by Peter Brown

1 The vagaries of publishing have seen the simultaneous appearance in France of two complete versions of Lu Xun's collection Wandering, only seven of whose eleven texts had hitherto been available in French ${ }^{1}$. The one by Sébastian Veg, being considered here, is a scholarly edition, accompanied by copious amounts of critical material in the form of very detailed footnotes and "notes" offering a personal interpretation for each of the short stories. The whole is complemented by the annotated translation of and commentary on an essay by Lu Xun entitled "The divergent paths of literature and political power", and crowned by a long postface. The volume's author has a deep and extensive knowledge of Lu Xun's work, as well as of studies devoted to him, as attested by his bibliography.

2 Sébastian Veg sets out his principles of translation in his preface : "We have sought to give quite a different reading of $\mathrm{Lu}$ Xun, one that does not conceal the roughness of a particular syntax of modern literary Chinese working itself out" (p. 7). However, it is not sure that this bias in favour of the literal (based on Lu Xun's own views as a translator) serves the text well. The "faithfulness" called for by the translation is in fact based in large measure on an illusion and some standard means of expression, characteristic of Chinese, seem to have been taken for peculiarities of $\mathrm{Lu}$ Xun's language (or of the language of the time). Repetitions, for example, are a feature of Chinese and are no more salient in the work of Lu Xun than they are in any other modern author, and one must be careful, the odd exception aside, not to keep them intact. A good many of the clumsy or bizarre expressions that can be found spread through the work are not imputable to Lu Xun, but to an inadequacy of the rendition of 
common turns of phrase ${ }^{2}$. In a word, all the coarseness that one finds in Lu Xun's style does not justify his being turned into an author who writes badly. Examples abound of such clumsiness being needlessly added onto the original text ${ }^{3}$.

The presentation of the commentaries in the form of separate notes has the advantage of bringing the reader into the detail of each text. On the other hand, it does not allow for any distinction to be made between the largely symbolic stories such as "The Lamp that was Kept Alight" or "Soap" and the more complex narratives such as, for instance, "The New Year's Sacrifice" or "Regret for the Past". Yet, this is a distinction which Sébastian Veg does bear in mind, since he refers in his postface to a "hesitation between a writing that is more political and one that is more poetic" (p. 300). Above all, the commentaries are too systematically reduced to the single problematic of tradition and modernity (or Westernisation), neglecting the simply human interest or curiosity that $\mathrm{Lu}$ Xun brings to certain types of characters born from an observation of his contemporaries, or indeed from his own introspection. While the critic recognises that "there is an affective tradition that goes beyond the denunciation of tradition" (p. 318), he does not draw out the full consequences of this. His interpretation of the story "The Misanthrope" is a case in point. The contradictions besetting a society given over to profound self-examination are not confined to a debate between progressives and conservatives, or even to a sincerity/hypocrisy dichotomy. Rather, they take the form of a friction in the heart of individuals between several duties and allegiances. The "ambiguities" of Wei Lianshu criticising the family, but sending his salary to his grandmother, are not ideological in nature, but emotional. I for one do not believe that $\mathrm{Lu}$ Xun's goal in writing his short stories is to "define an minimal ethical position" (p. 258), but rather to bear witness to the moral suffering of individuals driven by heavy demands, yet incapable of seeing them through. The torments of this "misanthrope", whose self-destructive ways are followed sympathetically by the narrator, are somewhat reminiscent in fact of the wily personality of Zhu Ziqing's Wei Woqing, that erudite man who hides his wounds under a succession of masks ${ }^{4}$.

4 "Regret for the Past", a text which to my mind is more melancholic than satirical, relates the conflict, in the male intellectual, between the great ideals and the trivial necessities of daily life, between devotion to abstractions and one's humdrum duties to one's surroundings. In short, it raises the question of how to remain faithful to one's ambitions without hurting those around. "A Happy Family" is a humorous depiction of the condition of writers, doomed to the great gulf between ideals and material reality. As for "Master Gao", more than a merciless condemnation of the May Fourth intellectual, it is above all a satire on the mediocrity of chinese teachers and their hybrid mentality that Lao She was to depict with a more sustained humour in The Philosophy of Lao Zhang ${ }^{5}$. It is true that Lu Xun has a pessimistic view of the tendencies of his times, but to condense the contradictions and frailties of the human heart, such as he analyses them, to the "hypocrisy" of the modern intellectual is rather reductionist. This could not, for example, adequately characterise the attitude of Peijun ("Brothers") to traditional medicine, in so far as emergency situations can easily undo theoretical certainties. As for the dream in which he brutalises his brother's children, it is in my view an expression of Peijun's guilty conscience. He does not "dream" of beating the children, but he knows, in his subconscious, that if necessary, he would sacrifice them without hesitation for the good of his people. Such are the limits of brotherly love cruelly highlighted by Lu Xun. 
5 I might add that all the symbols are not necessarily or exclusively political, and, without rejecting Sébastian Veg's interpretation of the "flowers in the snow" ("In the Tavern"), which are said to refer "both to the beauty of traditional china hidden beneath the winter snow of modernity and to the hope of renewal" (p. 226), I would readily suggest another reading, showing the desire of people to live that is buried under the harshness of existence.

Beyond any differences in focus-which bear witness no doubt in the first instance to the multiplicity of readings sanctioned by Lu Xun's work-, some of the commentator's statements seem to me debatable. Whatever the well-rehearsed conflicts that opposed $\mathrm{Lu}$ Xun to romantic writers, it is hard to see that the story "A Happy Family", in which a writer tries to extricate himself from the real world in order to imagine an ideal couple, is aimed at the hypocrisy of the authors of the Creation Group, since, from Guo Moruo to $\mathrm{Yu}$ Dafu, these writers have in fact never stopped writing into their works characters who are confronted with disastrous material circumstances. In "The New Year's Sacrifice", nothing leads one to think that the sister-in-law Xiang Lin has committed suicide, particularly given that, struck as she is by Mother Liu's speeches, she is afraid of being sawn in half in hell. It is quite true, on the other hand, that the narrator feels guilty for having hastened her death by driving her to despair, due to his inability to provide her with any soothing response. We should note in passing that while it is indeed possible to talk of the reader being arraigned (p.221), in the context this concerns the Chinese reader who is a contemporary of Lu Xun. Foreign readers will find themselves rather at a critical distance from what they will perceive as manifestations of Chinese insensitivity. In other words, implicating the reader at the same time as the narrator is here related to collective self-criticism.

7 The essay attached to the collection, the text of a lecture delivered in 1927 at Jinan University in Shanghai, although coming two years after Wandering, casts a very interesting light on Lu Xun's own understanding of the work of a writer. Above all, as Sébastian Veg points out, it muddles "the orthodox communist view of Lu Xun which prevailed after 1949" (p. 290). I would certainly not claim, however, that "the idea of revolutionary literature is a nonsense for Lu Xun" (p. 294), but rather that he rejects the definition given to it by those who proclaim themselves to be "revolutionary writers" and the idea that literary activity and revolutionary activity can be one and the same. First, because literature requires leisure time, and one cannot both write and fight at once, whence a necessary modesty on the part of the writer, conscious of his powerlessness (a point on which $\mathrm{Lu}$ Xun's position is not that far from that of his brother Zhou Zuoren ${ }^{6}$ ). Secondly, because vigilance is always relevant, and that any revolution runs the risk of giving rise to a new power that is just as oppressive-here we can admire Lu Xun's prescient lucidity-and will again force writers either to secede or to sacrifice their lives.

8 The reader will have understood that the publication of the complete collection Errances (Wandering) is above all else an invitation to read and reread Lu Xun. It is only to be regretted, however, that the present edition, which is otherwise very rich, stimulating and well documented, does little, finally, to correct the "ideological image" of the great writer through its insistence on focusing, sometimes in an oversimplified way, on the supposed role of tribune played by his texts. 


\section{NOTES}

1. At the same time You-Feng (Paris, 2004, 213 pp.) published an edition of the short stories of Errances, the cover of which announces that the translation is purportedly due to Jacques Meunier, but which, if we are to judge by the introduction (dating from 1994) and the "Translators' note to the readers", seems to have been prepared by Michelle Loi. We should also observe the almost simultaneous publication by Editions en langues étrangères (Peking, 2004, 309 pp., without any mention of the translator), in a bilingual and apparently revised version, of the seven stories that were previously brought together in Volume 1 of Euvres choisies de Lu Xun [Selected Works of Lu Xun] (Peking, Éditions en langues étrangères, 1981).

2. Thus p. 20 : "She was not so poor as to die from it ?", which is a curious translation for the resulting banal phrase "to die from poverty".

3. Here are some (lack of space does not allow me to cite them all) : "those who beg are only men" (p. 16) ; “I couldn't prevent myself from suddenly realising it" (p. 114); “I didn't understand from where, whilst I clearly possessed my grandmother, I could still hold my 'own grandmother"' (p. 125).

4. Zhu Ziqing, "Huai Wei Woqing jun" (In remembrance of Mr Wei Woqing) (1928), in Beiying (The Silhouette Seen from Behind), Peking, Zhongguo qingnian chubanshe, 1995, pp. 71-75.

5. Lao She, Lao Zhang de zhexue (1926).

6. See in this connection Bê-Duc Thê, "Writing all the same : Zhou Zuoren and the wager of writing", in Isabelle Rabut and Angel Pino (eds.), Pékin - Shanghai : tradition et modernité dans la littérature chinoise des années trente (Peking-Shanghai : Tradition and Modernity in Chinese Literature of the 1930s), Paris, Bleu de Chine, 2000, pp. 193-218. 